EXPANDED ABSTRACT

\title{
MANAGING INVASIVE ANIMALS ON SUB-ANTARCTIC ISLANDS
}

\author{
by K. G. Broome
}

\begin{abstract}
Broome, K.G. 2009 (11:xii) Managing invasive animals on sub-Antarctic islands. Papers and Proceedings of the Royal Society of Tasmania 143(1): 53-55. https://doi.org/10.26749/rstpp.143.1.53 ISSN 0080-4703. Department of Conservation, PO Box 516, Hamilton 3240, New Zealand. Email: kbroome@ doc.govt.nz
\end{abstract}

People have deliberately or accidentally introduced animals to many sub-Antarctic islands over the past 25 years. Environmental changes as a consequence of these introductions can be inferred from observations made directly before or following eradication. Broad options for managing invasive animals include prevention, eradication, sustained control or no control, circumstances usually dictating the best option. Examples of successful management of invasive animals in the sub-Antarctic region include Enderby and Campbell islands. Key challenges in furthering management of invasive animals in the region include improving biosecurity to prevent pests reaching new locations (including islands from which they may have been eradicated) and increasing the scale of islands on which eradication of rodents is attempted. Success with the Macquarie Island rabbit eradication project will greatly increase understanding and confidence in what can be done.

Key Words: sub-Antarctic islands, human impacts, invasive alien species, conservation, management, eradication.

\section{INTRODUCTION}

Island habitats represent only three per cent of the Earth's land area but island species make up $64 \%$ of the world's known extinctions and $45 \%$ of endangered species are known to occur on islands. This paper provides an overview of invasive animals in the sub-Antarctic to give context to a project currently underway to eradicate European Rabbits Oryctolagus cuniculus (Linnaeus, 1758) and rodents from Macquarie Island (12 800 ha). Management of other invasive species in the region such as plants and pathogens, whilst important, is not considered.

\section{HISTORY}

The sub-Antarctic region is mostly ocean, making terrestrial habitats both scarce and important for many species of wild life including marinespecies which comeashore to breed. Humans have deliberately or accidentally introduced animals to many of these islands over the past 250 years (Convey 2007, King 2005, Torr 2002, Atkinson 1985). Deliberate releases in the eighteenth and nineteenth centuries were intended to provide a ready source of wild food for sealers and shipwrecked sailors. Attempts at farming on some islands met with mixed success and led to abandoned or feral herds (Fraser 1986). Rodents commonly reached islands accidentally, carried in equipment orstores (Atkinson 1985, Taylor 2006). A few birds, such as the European Starling, Sturnus vulgaris Linnaeus, 1758, arrived unassisted as a consequence of their deliberate introduction to inhabited countries further north.

Only a small number of islands remain free of pest animals in the sub-Antarctic region, mainly due to a combination of chance and their relative lack of human activity. Although successful eradication projects have removed pest animals from a few islands, at least one species of invasive animal occurs on the majority of islands in the region (Convey 2007, Atkinson 1985, Smith 2007).

\section{IMPACTS}

We can infer the environmental changes attributable to invasive animals in the region from differences between similar islands with and without particular species or from observations of the successful reintroduction or recolonisation of extirpated native species following eradication of pests. The endemic flightless Campbell Island Teal, Anas aucklandica nesiotis (Fleming, 1935), provides an example of the latter. Not seen in living memory on Campbell Island, ornithologists rediscovered it on nearby Dent Island (23 ha) in 1975 (Williams \& Robertson 1996). Reintroductions of captivebred teal following the successful eradication of Norway Rats (Brown Rats), Rattus norvegicus (Berkenhout, 1769), from Campbell Island in 2001 have led to a viable breeding population requiring no further management.

Introduced House Mice, Mus musculus Linnaeus, 1758, studied on Gough Island were observed attacking Tristan Albatross, Diomedea dabenena Brooke, 2004, chicks on their nests, causing massive wounds and leading to the death of about half the chicks produced (Angel et al. 2006).

The impacts of herbivorous animals can be inferred by using fenced plots which exclude the pest from the vegetation. Changes in flora within the fence are compared with those outside where access to grazing remains. Examples occur on Macquarie Island where vegetation recovery following the removal of rabbit grazing is apparent (Carmichael 2009).

\section{OPTIONS FOR MANAGEMENT}

There are four broad options for managing invasive animals in the sub-Antarctic region:

- Prevention - Preventing further spread of invasive species is the most cost-effective option for all sub-Antarctic islands. Taking steps to prevent further invasions should be the highest pest management priority even where islands already have some animal pests established.

- Eradication - Totally removing the pest population, where feasible, offers a permanent solution provided reinvasion (see option 1) and undesirable consequences of eradication are managed. 
- Sustained control - Ongoing population control is a complex option to manage the impacts of introduced species in perpetuity, either through chemical, physical or biological means. The benefits dissipate if control stops, so sustaining the effort is important and can be difficult in terms of technology, logistics and politics.

- No control - A choice to do nothing could be justified in three ways: first, if the benefits of management action do not outweigh the costs; second, a lack of capability to undertake the work; and third, a lack of priority for available resources. Typically managers invest in research which may investigate potential benefits and costs or to build the knowledge and capability to address the problem or support the justification for priority. Nevertheless, until management action is taken, research effort remains technically within the "no control" option.

There are six components to successful invasive species management (Broome \& Fairweather 2008):

- An understanding of the problem and how each pest species contributes to this, e.g., recruitment failure through egg predation by Black Rats, Rattus rattus (Linnaeus, 1758), versus mortality of fledglings by Brown Skua, Stercorarius antarcticus (Lesson, 1831), as a result of burrow entrances exposed through rabbit grazing.

- A strategy which clearly articulates goals and priorities.

- Technology and equipment which does the job effectively and efficiently.

- Skills and experience to carry out the required tasks competently.

- Funding.

- Community acceptance of the strategy, funding and technology being used.

\section{EXAMPLES OF PEST MANAGEMENT IN THE SUB-ANTARCTIC REGION}

Enderby Island in the Auckland group had cattle introduced in a failed attempt at farming and rabbits introduced as castaway food for shipwrecked sailors. Mice probably arrived in the mid-nineteenth century. The cattle were eradicated in the early 1990s. In 1993 a helicopter was used to spread poison bait for rabbits and mice. A hunting team followed up immediately afterwards to remove the last surviving rabbits (Torr 2002). Enderby Island is now free of introduced mammals.

In 2001, Department of Conservation staff targeted Norway Rats on Campbell Island with aerially-applied poison baits, this time using Global Positioning System (GPS) navigational guidance to fly parallel flight lines across the island. At 11300 ha Campbell Island had a far bigger area than previous eradication programs had attempted, but careful planning and dedicated personnel resulted in successful eradication (McClelland \& Tyree 2002).

Tasmanian Parks and Wildlife Service staff successfully eradicated Weka, Gallirallus australis scotti (Ogilvie-Grant, 1905), and Feral Cats, Felis catus Linnaeus, 1758, from Macquarie Island. The work currently underway on this island targets the final three animal pests (mice, Black Rats and rabbits) in a single project involving aerial poison baiting and follow-up hunting of surviving rabbits (Parks \& Wildlife Service 2007). The scale of Macquarie Island (12 800 ha) looks challenging compared with previous attempts for mice and rabbits. Campbell Island is similar in size but the operation was comparatively simple in targeting a single pest species. However, Campbell Island managers faced similar issues in 2001: a lack of comparable precedents alone does not determine feasibility.

\section{FUTURE OPPORTUNITIES AND CHALLENGES}

Opportunities exist throughout the region for further management work on invasive animals. Continued sharing of expertise and lessons gained from each project will give the greatest chance of success. Priority setting should consider opportunities to consolidate the management of biosecurity, by reducing the potential for animals to be spread from one island to another within the region, as well as to provide further pest-free environments for the flora and fauna that inhabit this region.

Invasive animal management in the region faces two key challenges. The first is to address the issue of biosecurity to stop pests moving to new islands or islands from which they have been eradicated. Finding innovative solutions to effective quarantine management, efficient surveillance systems to provide early warning, and reliable capacity to respond to incursions on such remote and logistically difficult islands is the challenge to be overcome. Island quarantine can be regarded as a social problem as it is within the control of humans visiting islands to minimise the risks given the right information, motivation and ability to act. Management agencies should lead by example and work to create an environment of shared values, understanding of risk and willingness to constantly improve.

The second major challenge is developing the technology to make another leap of scale in the size of islands on which the eradication of rodents is attempted. The Macquarie Island project will test the limits of scale using existing techniques.

However, far larger islands in the region could benefit from rodent eradication, if the attempt can be made logistically feasible and affordable. For example, the eradication of mice from the 50000 ha Auckland Island using current techniques would require 800 tonnes of poison bait applied to the island. The logistics of such an exercise become overwhelming in such a challenging environment.

\section{REFERENCES}

Angel, A., Brown, D., Cooper, J., Hilton, G. \& Sanders, S. 2006: The introduced rodents of Tristan da Cunha and Gough Islands (South Atlantic): Impacts and management options. RSPB Research Report no. 17.

Atkinson, I.A.E. 1985: The spread of commensal species of Rattus to oceanic islands and their effects on island avifaunas. In Moors, P.J. (ed.): Conservation of Island Birds. ICPB Technical Publication No. 3: 35-81.

Broome, K. \& Fairweather, A. 2008: Pesticide use for biodiversity management 1987-2007. In Clarkson, B., Kruian, P., Nachowitz, T. \& Rennie, H. (eds): Proceedings of the Consery-Vision Conference, University of Waikato, 2-4 July 2007. University of Waikato, Hamilton, New Zealand. www.waikato.ac.nz/wfass/conserv-vision

Carmichael, N. 2009: Macquarie Island Rabbit Grazing Damage Survey Project 2005 to 2007 (work in progress), Conference poster, Second International Forum on the sub-Antarctic, Hobart, Australia, April 2009. Unpublished.

Convey, P. 2007: Influences on and origins of terrestrial biodiversity of the sub-Antarctic islands. Papers and Proceedings of the Royal Society of Tasmania 141(1): 83-93. 
Fraser, C. 1986: Beyond the Roaring Forties: New Zealand's SubAntarctic Islands. Government Printing Office, Wellington: $214 \mathrm{pp}$.

King, C.M. (ed.) 2005: The Handbook of New Zealand Mammals. Second Edition. Oxford University Press, Oxford: xx pp.

McClelland, P. \& Tyree, P. 2002: Eratication: The clearance of Campbell Island. New Zealand Geographic 58: 86-94.

Parks \& Wildlife Service 2007: Plan for the Eradication of Rabbits and Rodents on Sub-Antarctic Macquarie Island: Part A: Overview and Justification. Department of Environment, Parks, Heritage and the Arts, Canberra, ACT; Department of Primary Industries and Water, Hobart, Tasmania: 610 pp.

Smith, V.R. 2007: Terrestrial ecological processes and problems on Sub-Antarctic islands. Papers and Proceedings of the Royal Society of Tasmania 141(1): 99-109.
Taylor, R.H. 2006: Straight Through from London: The Antipodes and Bounty Islands, New Zealand. Heritage Expeditions NZ Ltd, Christchurch: 415 pp.

Torr, N. 2002: Eradication of rabbits and mice from sub-Antarctic Enderby and Rose islands. In Veitch, C.R. \& Clout, M.N. (eds): Turning the Tide: the Eradication of Invasive Species. IUCN SSC Invasive Species Specialist Group. Gland, Switzerland and Cambridge, UK: 319-328.

Williams, M. \& Robertson, C.J.R. 1996: The Campbell Island teal Anas aucklandica nesiotis: history and review. Wildfowl 47: 134-165.

(accepted 3 November 2009) 